\title{
Localization of Protein Kinase Activity and Phosphoproteins in Mitoplasts from Rat Liver
}

\author{
THOMAS HENRIKSSON and BENGT JERGIL
}

\author{
Biochemistry, Chemical Centre, P.O.B. 740, S-220 07 Lund, Sweden
}

Rat liver mitoplasts (inner mitochondrial membrane and matrix) contain protein kinase activity. This activity increases twofold on addition of Triton X100 . The activity observed in absence of Triton X100 is probably exposed on the outer surface of mitoplasts, since it is sensitive to trypsin treatment. Most of the remaining protein kinase is bound to the membrane fraction, presumably on the inside of (or else hidden in) the inner mitochondrial membrane. Only a small part of the kinase activity is found in the mitochondrial matrix. A phosphoprotein band, partly resolved into a doublet, was observed on electrophoresis in SDS-polyacrylamide gels after endogenous phosphorylation of mitoplasts, innner mitochondrial membrane or matrix. When isolated fractions are phosphorylated approximately $75 \%$ of the phosphoprotein is found in the matrix, and the remainder in the inner membrane. The phosphorylation of the doublet is inhibited by inhibitors to pyruvate dehydrogenase kinase, suggesting that it represents the phosphorylated subunit of pyruvate dehydrogenase.

In rat liver cells protein kinases and endogenous substrates for these enzymes have been found both in soluble ${ }^{1,2}$ and particulate ${ }^{3,4}$ fractions including mitochondria. ${ }^{5-8}$ The mitochondrial protein kinase activity is distributed in various submitochondrial fractions, including outer membranes, the intermembrane fraction and mitoplasts. ${ }^{8}$ This enzyme can be separated into 2 or 3 subfractions by DEAE-cellulose chromatography. ${ }^{8,9}$

Although various mitochondrial functions are under hormonal regulation, which often involves phosphorylation/dephosphorylation of specific proteins, comparatively little is known about protein phosphorylation in liver mitochondria. The only mitochondrial phosphoproteins detected in our earlier study ${ }^{8}$ were located in the mitoplast fraction. In other tissues pyruvate dehydrogenase is the only mitochondrial protein which is known to be phosphorylated. ${ }^{10-12}$ This report concerns the further localization of protein kinases and phosphoproteins within the inner mitoplast fraction. Evidence is presented that the mitoplast phosphoproteins represent pyruvate dehydrogenase.

\section{EXPERIMENTAL}

Chemicals. Inorganic $\left[{ }^{32} \mathrm{P}\right]$-phosphate was obtained from the Radiochemical Centre, Amersham. $\left[\gamma^{32} \mathrm{P}\right]$ ATP was synthesized according to Chang et al. ${ }^{13}$ Protamine sulfate, trypsin, bovine serum albumin (A 6003) and altractyloside were from Sigma. Acrylamide was from Bio-Rad and $N, N^{\prime}$-methylene bisacrylamide (twice recrystallized from acetone) from Eastman. All other chemicals were of reagent grade.

Methods. Mitoplasts were prepared as described earlier. ${ }^{8}$ They were subfractionated into inner membranes and matrix as follows. Mitoplasts were suspended in distilled water and frozen and thawed 3 times, followed by centrifugation at $35000 \times g$ for $20 \mathrm{~min}$. After decanting the supernatant, the above procedure was repeated once. The combined supernatants contained the mitochondrial matrix material, and the pellet consisted of the inner membrane as judged by the distribution of the marker enzymes cytochrome oxidase (inner membrane) (measured as described in Ref. 14, but using an extinction coefficient of $\left.21 \mathrm{mM}^{-1} \mathrm{~cm}^{-1}\right)^{15}$ and glutamate dehydrogenase ${ }^{16}$ (matrix). The result of the subfractionation and the degree of crosscontamination is shown in Table 1.

Protein kinase activity was determined as described earlier. ${ }^{8,17,18}$ Protein was measured by 
Table 1. Distribution of marker enzymes in subfractionated mitoplasts. Livers from three rats were combined and mitoplasts were prepared and subfractionated as described in Experimental. Enzyme analyses were performed in duplicate. Enzyme activities are expressed as $\mu \mathrm{mol} \min ^{-1}$ $\mathrm{mg}^{-1}$ protein.

\begin{tabular}{llll}
\hline Fraction & $\begin{array}{l}\text { Protein } \\
\text { (mg/g } \\
\text { liver) }\end{array}$ & $\begin{array}{l}\text { Cytochrome } \\
c \\
\text { oxidase }\end{array}$ & $\begin{array}{l}\text { Glutamate } \\
\text { dehydro- } \\
\text { genase }\end{array}$ \\
\hline $\begin{array}{l}\text { Mitoplasts } \\
\text { Inner }\end{array}$ & 1.96 & 2.29 & 0.921 \\
$\begin{array}{l}\text { membrane } \\
\text { Matrix }\end{array}$ & 1.01 & 2.08 & 0.163 \\
\hline
\end{tabular}

the Lowry method ${ }^{19}$ after precipitation with 7\% trichloroacetic acid in the presence of $0.015 \%$ sodium deoxycholate. ${ }^{20}$ Bovine serum albumin was used as a standard.

Proteolytic digestion of mitoplasts (protein concentration $7-12 \mathrm{mg} / \mathrm{ml}$ ) was performed with trypsin using a trypsin to protein ratio of 1:50 $(\mathrm{w} / \mathrm{w}) .^{21}$ The digestion proceeded for $18 \mathrm{~h}$ at $0^{\circ} \mathrm{C}$ and was stopped by addition of a threefold excess $(w / w)$ of soybean trypsin inhibitor.

Endogenous phosphorylation for electrophoresis was performed as described earlier ${ }^{8}$ using $50 \mu \mathrm{g}$ of protein in a total volume of $50 \mu$ l. The incubation time was $5 \mathrm{~min}$.

Sodium dodecylsulfate (SDS)-polyacrylamide gel electrophoresis was performed in slab gels using the buffer system of Laemmli. ${ }^{22}$ The total monomer content of the separation gel was $10 \%$ and the proportion of crosslinker was $2.5 \%$. The electrode buffer contained $0.0083 \mathrm{M}$ Tris and $0.192 \mathrm{M}$ glycine (pH 8.1). The procedure for electrophoresis and autoradiography has been described in detail earlier. ${ }^{8}$ The following standard proteins were used: bovine serum albumin, $M_{\mathrm{r}} 69000$; ovalbumin, $M_{\mathrm{r}}$ 45000; soybean trypsin inhibitor, $M_{\mathrm{r}} 21500$; and sperm whale myoglobin, $M_{\mathrm{r}} 17200$.

Endogenous phosphorylation of proteins was measured by cutting out the phosphoprotein bands from SDS-polyacrylamide gels and counting the pieces in a liquid scintillation counter using $0.4 \%$ Omnifluor (New England Nuclear) in toluene as scintillation liquid. The doublet band at $M_{\mathrm{r}} \mathbf{4 4 0 0 0}$ -45000 was counted as one band. The blank used was an equal size part of the gel from a corresponding region without phosphoprotein bands.

When testing the influence of effectors of pyruvate dehydrogenase kinase on the phosphorylation of proteins the conditions of Morgan and Routtenberg ${ }^{12}$ were used. After incubation the samples were subjected to electrophoresis and scintillation counting as described above. Tests were run in triplicate.

The influx of ATP into mitoplasts was measured by incubation in the following mixture: $50 \mathrm{mM}$ Tris$\mathrm{HCl}, \mathrm{pH} 7.7,10 \mathrm{mM} \mathrm{MgCl}_{2}, 1 \mathrm{mM}$ dithioerythritol, $0.5 \mathrm{mM}\left[\gamma-{ }^{32} \mathrm{P}\right]$ ATP $(10000-30000 \mathrm{dpm} / \mathrm{nmol})$ and $5 \mathrm{mg} / \mathrm{ml}$ mitoplastic protein. To study the timedependency $50 \mu \mathrm{l}$ samples were withdrawn at appropriate times and the reaction was stopped by mixing with an equal volume of $5 \mathrm{mM}$ atractyloside (a potent ATP carrier inhibitor), $2 \mathrm{mM}$ HEPES, $\mathrm{pH}$ 7.5, $0.22 \mathrm{M}$ mannitol and $0.07 \mathrm{M}$ sucrose. This mixture was layered over $200 \mu \mathrm{l}$ of $5 \mathrm{mM}$ atractyloside, $2 \mathrm{mM}$ HEPES, $\mathrm{pH} 7.5,0.22 \mathrm{M}$ mannitol and $0.65 \mathrm{M}$ sucrose in a $400 \mu \mathrm{l}$ centrifuge tube to a Beckman Microfuge. The sample was centrifuged for $11 / 2 \mathrm{~min}$ and the supernatant was carefully removed. The pellet was then counted in 5 $\mathrm{ml}$ Biofluor (New England Nuclear). The influx of ATP was linear for at least $10 \mathrm{~min}$.

\section{RESULTS}

Localization of protein kinase. As we have previously shown ${ }^{8}$ purified rat liver mitoplasts possess a protein kinase activity that can phosphorylate exogenous substrates. The phospho-

Table 2. Effect of trypsin treatment on protein kinase activity in mitoplasts. Intact mitoplasts, or mitoplasts solubilized in $1 \%$ Triton $\mathrm{X}-100$, were incubated with trypsin for $18 \mathrm{~h}$ at $0{ }^{\circ} \mathrm{C}$ as described in Experimental. Protein kinase assays were performed in the absence or presence of $1 \%$ Triton $\mathrm{X}-100$. Each experiment includes the combined material from three rats.

\begin{tabular}{|c|c|}
\hline & $\begin{array}{l}\text { e activity } \\
\text { mg protein }\end{array}$ \\
\hline- & $\begin{array}{l}+1 \% \\
\text { Triton X-100 }\end{array}$ \\
\hline
\end{tabular}

\section{Experiment 1}

$\begin{array}{lrr}\text { Mitoplasts } & 10.2 & 22.3 \\ \text { Mitoplasts + trypsin } & 2.2 & 13.5 \\ \text { Solubilized mitoplasts } & & 4.6 \\ \text { + trypsin } & \end{array}$

\section{Experiment 2}

\begin{tabular}{lrr} 
Mitoplasts & 11.8 & 23.4 \\
Mitoplasts + trypsin & 3.5 & 16.5 \\
Solubilized mitoplasts & & 6.2 \\
+ trypsin & & \\
\hline
\end{tabular}


Table 3. Protein kinase activity and endogenous incorporation of $\left[{ }^{32} \mathrm{P}\right]$-phosphate into proteins of subfractionated mitoplasts. Each experiment includes material from three rats. Protein kinase activity was determined in the presence or absence of $5 \mu \mathrm{M}$ cyclic AMP using protamine as a substrate. The endogenous incorporation of phosphate was not affected by cyclic AMP and was measured in the absence of the nucleotide.

\begin{tabular}{|c|c|c|c|c|c|c|}
\hline \multirow[t]{3}{*}{ Fraction } & \multicolumn{4}{|c|}{ Protein kinase activity } & \multicolumn{2}{|c|}{$\begin{array}{l}\text { Endogenous incorporation } \\
\text { of }\left[{ }^{32} \mathrm{P}\right] \text {-phosphate }\end{array}$} \\
\hline & \multicolumn{2}{|c|}{$\begin{array}{l}\text { Specific } \\
\text { (pmol min } \\
\mathrm{mg}^{-1} \text { protein) }\end{array}$} & \multicolumn{2}{|c|}{$\begin{array}{l}\text { Total } \\
\text { (pmol min } \mathrm{g}^{-1} \\
\text { liver) }\end{array}$} & \multirow[t]{2}{*}{$\begin{array}{l}\text { Specific } \\
\text { (pmol mg } \\
\text { protein }\end{array}$} & \multirow[t]{2}{*}{$\begin{array}{l}\text { Total } \\
\text { (pmol } \mathrm{g}^{-1} \\
\text { liver) }\end{array}$} \\
\hline & - & + & - & $+\mathrm{cA}$ & & \\
\hline \multicolumn{7}{|l|}{ Experiment 1} \\
\hline $\begin{array}{l}\text { Mitoplasts } \\
\text { Mitoplasts + }\end{array}$ & 6.14 & 6.98 & 15.7 & 17.9 & 30.6 & 108 \\
\hline $1 \%$ Triton $X-100$ & 9.50 & 13.2 & 24.3 & 33.8 & - & - \\
\hline Inner membrane & 9.52 & 10.5 & 11.3 & 12.5 & 8.7 & 13.4 \\
\hline $\begin{array}{l}\text { Inner membrane }+ \\
1 \% \text { Triton X-100 } \\
\text { Matrix }\end{array}$ & $\begin{array}{c}19.6 \\
1.89\end{array}$ & $\begin{array}{c}22.0 \\
1.66\end{array}$ & $\begin{array}{r}23.3 \\
2.2\end{array}$ & $\begin{array}{r}26.1 \\
2.0\end{array}$ & $\overline{28.5}$ & $\overline{46.6}$ \\
\hline \multicolumn{7}{|l|}{ Experiment 2} \\
\hline $\begin{array}{l}\text { Mitoplasts } \\
\text { Mitoplasts + }\end{array}$ & 10.4 & 11.9 & 20.4 & 23.3 & 33.8 & 183 \\
\hline $1 \%$ Triton X-100 & 19.2 & 23.4 & 37.6 & 45.9 & - & - \\
\hline $\begin{array}{l}\text { Inner membrane } \\
\text { Inner membrane }+\end{array}$ & 16.3 & 18.5 & 16.5 & 18.8 & 8.1 & 15.9 \\
\hline Triton X-100 & 33.8 & 33.8 & 34.2 & 34.2 & - & - \\
\hline Matrix & 4.1 & 6.0 & 3.6 & 5.3 & 17.6 & 33.6 \\
\hline
\end{tabular}

rylating activity increases approximately twice on addition of Triton X-100. Presumably this is due to the fact that a part of the protein kinase is located either within the mitoplast membrane or in the mitochondrial matrix, and that the enzyme therefore cannot interact with the added protein substrate.

In order to examine this hypothesis, mitoplasts were treated with trypsin and then analyzed for protein kinase activity in the presence and absence of Triton X-100 (Table 2). The activity obtained without detergent decreased by approximately $80 \%$ upon trypsin treatment, while the latent activity (i.e. the increase in activity seen after the addition of Triton) was unaffected. The control experiment where mitoplasts were trypsinized in the presence of Triton X-100 showed that the latent protein kinase was equally sensitive to the protease as the exposed activity. In another control experiment where both soybean trypsin inhibitor and Triton X-100 were present during the trypsin treatment there was no decrease in protein kinase activity (not shown). These results suggest a surface location of approximately half the protein kinase activity of mitoplasts (using protamine as a substrate), while the remaining activity is located either in the matrix or on the inside of (or else hidden in) the inner mitochondrial membrane.

The location of the protein kinase was further examined in mitoplasts subfractionated into inner membranes and matrix (Table 3). Approximately $10 \%$ of the recovered protein kinase was found in the matrix. The remaining activity appeared in the inner membrane subfraction, and showed the same latency as the protein kinase of mitoplasts. The kinase activity of the matrix was independent of detergent (not shown). The effect of cyclic AMP on enzyme activity was slight, both in mitoplasts and in the isolated subfractions.

Localization of phosphoproteins. When mitoplasts 

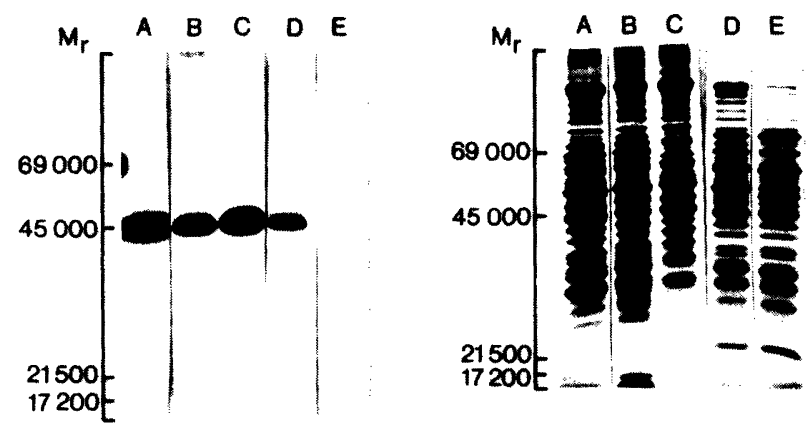

Fig. 1. Phosphoprotein and protein patterns of mitoplasts and mitoplast subfractions. Mitoplasts and subfractions were incubated with $\left[\gamma^{32} \mathrm{P}\right]$ ATP. They were subjected to SDS-polyacrylamide gel electrophoresis, and the gels were stained for protein (right) and autoradiographed (left). A, intact mitoplasts; $\mathrm{B}$, inner membrane; $\mathrm{C}$, matrix; D, trypsin-treated mitoplasts; $\mathrm{E}$, mitoplasts solubilized in Triton X-100 and then trypsin-treated. The $M_{\mathrm{r}}$ values of standard proteins are indicated on the left.

were incubated with $\left[\gamma_{-}{ }^{32} \mathrm{P}\right] \mathrm{ATP}$, radiolabelled phosphate was incorporated into two polypeptides that could be partly resolved by electrophoresis in SDS-polyacrylamide gels (Fig. 1). If mitoplasts were subfractionated and then phosphorylated, most of the recovered phosphoprotein was found in the matrix fraction (Table 3), although a substantial amount (approximately $25 \%$ ) was also found with the inner membrane.

When intact mitoplasts were trypsinized before phosphorylation there was a substantial decrease in protein phosphorylation, as can be seen from the intensity of the phosphorylation bands in Fig. 1. Since most phosphoprotein was recovered in the matrix and trypsin presumably acts on the mitoplast surface this appears contradictory. However, it is possible that the ATP-translocating system might be affected by the proteolytic treatment limiting the ATP available for phosphorylation. The uptake of ATP was therefore measured in untreated and trypsin-treated mitoplasts. The uptake decreased from 104 pmol of ATP per min per mg mitoplast protein to between $30-50 \%$ of this value by the trypsin treatment. ATP may therefore be limiting in the phosphorylation of mitoplast proteins after trypsin treatment.

Identification of the phosphoprotein. The only phosphoprotein identified in mitochondria up to now is pyruvate dehydrogenase with $M_{\mathrm{r}} 41000^{23}$ for the phosphorylated subunit. Morgan and Routtenberg $^{12}$ recently identified a double phosphoprotein band in rat brain mitochondria with a similar $M_{\mathrm{r}}$ as this enzyme. Although our phosphoprotein doublet has a higher $M_{\mathrm{r}}(44000$ -45000 ) the difference is within the limits expected for determinations by SDS-polyacrylamide gel electrophoresis.

To further identify the phosphoproteins the effect on phosphate incorporation into matrix phosphoproteins of various pyruvate dehydrogenase kinase modulators was tested (Table 4). It is seen that particularly dichloroacetate and pyruvate, but also NAD, inhibit this incorporation. These results are

Table 4. Modulation of the endogenous incorporation of $\left[{ }^{32} \mathrm{P}\right]$-phosphate into matrix protein. The mitochondrial matrix from three rats was incubated with $\left[\gamma^{-32} \mathrm{P}\right]$ ATP in the presence of the indicated compounds. The conditions of Morgan and Routtenberg ${ }^{12}$ were used. The incorporation of $\left[{ }^{32} \mathrm{P}\right]$-phosphate was measured as is described in Experimental. The incorporation is expressed as percent of control incubations in the absence of effectors.

\begin{tabular}{lcc}
\hline \multirow{2}{*}{ Effector } & \multicolumn{2}{c}{ Incorporation of } \\
& \multicolumn{2}{c}{$\left[{ }^{32} \mathrm{P}\right]$-phosphate $(\%)$} \\
\cline { 2 - 3 } & Exp. 1 & Exp. 2 \\
\hline None & 100 & 100 \\
1 mM NADH & 92 & 81 \\
1 mM NAD & 67 & 59 \\
5 mM dichloroacetic acid & 8 & 6 \\
5 mM sodium pyruvate & 18 & 13 \\
\hline
\end{tabular}


well in accordance with the results of Morgan and Routtenberg, ${ }^{12}$ and indicate that the phosphoprotein doublet in the matrix of rat liver mitochondria represents phosphorylated pyruvate dehydrogenase.

\section{DISCUSSION}

When studying the location of components in mitoplasts there are four different compartments to consider: the matrix, the outer and inner membrane surface and the lipid phase of the membrane. With the techniques used here it is possible to differentiate between three compartments (the lipid phase and the inner surface act as one compartment in these experiments).

It can be calculated from our results that approximately $90 \%$ of the total protein kinase activity of mitoplasts (using protamine as a substrate) is bound to the membrane, while the remaining activity resides in the mitochondrial matrix. Due to the increase in kinase activity on treatment of isolated inner membranes with Triton $\mathrm{X}-100$ and the partial sensitivity to trypsin treatment, around $50 \%$ of the membrane-bound activity appears to be located on the outer surface, while the rest is on the inner surface or else hidden in the membrane. Kleitke et al. ${ }^{9}$ have also found a latent protein kinase in a "highly purified mitochondria" fraction which seems to be similar to our mitoplast fraction. The relative amount of latent protein kinase reported by them is similar to what we have found here. They did not investigate the location of the kinase further, however.

The prosphoprotein was recovered primarily in the matrix, but approximately $25 \%$ was found in the inner membrane fraction. This is a much higher proportion than was found in the inner membrane of the matrix marker enzyme glutamate dehydrogenase (cf. Table 1). It appears, therefore, that the phosphoprotein has a rather high affinity for the membrane, and may be attached functionally to the inside of the inner membrane. The endogenous phosphorylation of the mitoplast proteins decreased after trypsin treatment. This decrease was probably due to an impairment of the transport of ATP over the membrane after trypsin treatment rather than to proteolysis of phosphorylatable proteins located on the mitoplast surface.

The only mitochondrial phosphoprotein iden- tified so far is pyruvate dehydrogenase. ${ }^{10}$ In rat brain mitochondria this enzyme appears as a phosphoprotein doublet of $M_{\mathrm{r}} 41000-42000 .^{12}$ This is lower than the $M_{\mathrm{r}} 44000-45000$ we observe for the phosphoprotein doublet of rat liver mitochondria. Since there is a very similar effect of various pyruvate dehydrogenase kinase modulators on the phosphorylation of these bands in brain and liver, it is likely that the liver phosphoproteins also represent pyruvate dehydrogenase. The observed discrepancy in molecular weight is probably due to the different buffer systems used for SDSpolyacrylamide gel electrophoresis in the two cases and the choice of molecular weight marker proteins.

The reason why the phosphoprotein appears as a doublet is not understood. The phosphorylation of both bands is affected similarly by trypsin treatment of mitoplasts or by pyruvate dehydrogenase modulators, and their relative proportion is the same after phosphorylation of either mitoplasts or isolated mitoplast subfractions. The fact that pyruvate dehydrogenase can incorporate up to three phosphate groups per enzyme subunit ${ }^{24}$ seems not to be the explanation for the appearance of two bands since their separation is based on differences in molecular weight rather than on charge.

In a previous paper ${ }^{8}$ we reported that protein kinases and phosphoproteins are distributed differently in rat liver mitochondrial fractions. The present work shows that protein kinases and phosphoproteins are also distributed differently in mitoplasts, with $90 \%$ of the kinases in the membrane fraction and $70 \%$ of the protein phosphorylation in the matrix fraction. It should be noted, however, that pyruvate dehydrogenase kinase is likely not to phosphorylate protamine or other common protein kinase substrates appreciably, ${ }^{24,25}$ and that the analyzed protein kinase activity therefore should be expected to phosphorylate some other substrate. Other phosphoproteins have not been observed, however, in our experiments. Whether this is due to the presence of powerful phosphoprotein phosphatases in mitochondria, or whether factors essential for phosphorylation have been removed or destroyed during the preparation procedure is not known presently. The appearance of protein kinase activity inside mitoplasts suggests that the enzyme is genuinely mitoplastic and not an enzyme which associates with the mitoplasts during the preparation procedure. 
Acknowledgement. This work was supported by the Swedish Natural Science Research Council.

\section{REFERENCES}

1. Rubin, C. S. and Rosen, O. M. Annu. Rev. Biochem. 44, (1975) 831.

2. Krebs, E. G. Curr. Top. Cell. Regul. 5 (1972) 99.

3. Zahlten, R. N., Hochberg, A. A., Stratman, F. W. and Lardy, H. A. Proc. Natl. Acad. Sci. U.S.A. 69 (1972) 800.

4. Jergil, B., Sommarin, M., Henriksson, T. and Schelin, C. In Krause, E.-G., Pinna, L. and Wollenberger, A., Eds., Cyclic Nucleotides and Protein Phosphorylation in Cell Regulation, Pergamon, Oxford 1979, p. 235.

5. Burnett, G. and Kennedy, E. P.J. Biol.Chem. 211 (1954) 969.

6. Lorina, M., Pinna, L. A., Moret, V. and Siliprandi, N. Biochim. Biophys. Acta 110 (1965) 636.

7. Vardanis, A. J. Biol. Chem. 252 (1977) 807.

8. Henriksson, T. and Jergil, B. Biochim. Biophys. Acta 588 (1979) 380.

9. Kleitke, B., Sydow, H. and Wollenberger, A. Acta Biol. Med. Ger. 35 (1976) K9.

10. Linn, T. C., Pettit, F. H. and Reed, L. J. Proc. Natl. Acad. Sci. U.S.A. 62 (1969) 234.

11. Wieland, O. and Siess, E. Proc. Natl. Acad. Sci. U.S.A. 65 (1970) 947.

12. Morgan, D. G. and Routtenberg, A. Biochem. Biophys. Res. Commun. 95 (1980) 569.

13. Chang, K.-J., Marcus, N. A. and Cuatrecasas, P. J. Biol. Chem. 249 (1974) 6854.

14. Shore, G. C. and Tata, J. R. J. Cell. Biol. 72 (1977) 714.

15. Hrycay, E.-G. and O'Brien, P. J. Arch. Biochem. Biophys. 160 (1974) 230.

16. Bergmeyer, H. V. Methoden der Enzymatischen Analyse, Verlag Chem., Weinheim 1970, p. 420.

17. Jergil, B. Eur. J. Biochem. 28 (1972) 546.

18. Jergil, B. and Dixon, G. H. J. Biol. Chem. 245 (1970) 425.

19. Lowry, O. H., Rosebrough, N. J., Farr, A. L. and Randall, R. J. Biol. Chem. 193 (1951) 265.

20. Peterson, G. Anal. Biochem. 100 (1979) 201.

21. Sommarin, M. and Jergil, B. Eur. J. Biochem. 88 (1978) 49.

22. Laemmli, U. K. Nature 227 (1970) 680.

23. Denton, R. M., Randle, P. J., Bridges, B. J., Cooper, R. H., Kerbey, A. L., Pask, H. T., Severson, D. L., Stansbie, D. and Whitehouse, S. Mol. Cell. Biochem. 9 (1975) 27.

24. Yeaman, S. J., Hutcheson, E. T., Roche, T. E., Pettit, F. H., Brown, J. R., Reed, L. J., Watson, D. C. and Dixon, G. H. Biochemistry 17 (1978) 2364.
25. Hucho, F., Randall, D. D., Roche, T. E., Burgett, M. W., Pelley, J. W. and Reed, L. J. Arch. Biochem. Biophys. 151 (1972) 328.

Received July 3, 1981. 